\title{
Web-based Population Administration Service Information System In Kutabumi Tangerang Village
}

\author{
Saryani ${ }^{* 1}$, Rohmawati Ningsih ${ }^{2}$, Puspita Indah Sari ${ }^{3}$ \\ 1,2,3 Universitas Raharja Fakultas Sains dan Teknologi Jurusan Sistem Informasi Konsentrasi \\ Business Intelligence \\ E-mail: *1 saryani@raharja.info, ${ }^{2}$ rohmawati@raharja.info. ${ }^{3}$ indah.puspita@raharja.info
}

To cite this document:

Saryani, S., Ningsih, R., \& Sari, P. I. (2020). A WEB-BASED POPULATION ADMINISTRATION SERVICE INFORMATION SYSTEM: IN KUTABUMI TANGERANG VILLAGE. IAIC Transactions on Sustainable Digital Innovation (ITSDI), 2(2), 192-196.

DOI : https://doi.org/10.34306/itsdi.v2i2.137

\begin{abstract}
The Kutabumi Kelurahan office is an office that carries out several activities to carry out government affairs, such as empowerment and service to the community. Population administration services are important in a government agency in the Kutabumi District Office. Problems that occur include the making of a request letter that is still semi-computerized using Microsoft Word and Microsoft Excel. So that the impact on services that are less effective and maximal to the needs of its residents. The system certainly has many weaknesses including the accumulation of paper and is vulnerable to data loss because the data is not stored in the database. To improve the existing quality services at the Kutabumi Village Office, an administrative service system is needed so that administrative services are more effective and efficient. The analytical method used by researchers is the PIECES method (Performance, Informance, Economy, Control, Efficiency, Service). With this administration system, it can facilitate the process of requesting requirements regarding population administration and facilitate service staff in the process of population administration report activities.
\end{abstract}

Keywords: Administration, Services, Application letter 


\section{Introduction}

In this modern era which has very high progress in all fields requires everything related to work to be completed more quickly and accurately. Along with the increasingly sophisticated development makes the need for information systems including government agencies such as Kelurahan can facilitate data processing activities and greatly affect the effectiveness and efficiency of work.

The administrative recording activity of each population service starts at the Kelurahan level and is forwarded to the Regency / City Government as the Government Agency that has the authority to record and manage population data. This requires that government agencies in the villages be able to provide services to the community quickly and professionally.

Community service information systems at government agencies such as the Kutabumi Kelurahan Office currently do not have a computerized and integrated system. One important factor in a government agency is the processing of population information data. In the Kutabumi District Office the population data processing is still done semi-computerically using Microsoft Excel in the process. So it does not rule out the possibility that making files or letters that will be made will occur due to human error. Archiving of letters is still done manually and file letters will accumulate. This can slow down the service process in adding data or inputing data or there can be a risk of errors in writing that can cause data redundancy which in the end makes the report can also take more time.

With this population information service, it can facilitate and accelerate service to the community, for example making a KTP application letter, birth certificate, death certificate, certificate of liability, and certificate of resettlement to make it more efficient and effective. The Governance Section of the Kutabumi Village Office, in its daily life, carries out considerable mobility in community administration services.

\section{Research Method}

The research method used is:

\section{Observation}

The method of data collection is by observing directly in the field so that an understanding of the research process can be obtained by visiting the object of research to the Kutabumi Village Office located in Kutabumi. In this observation method how to get data with an observation and carry out systematic records by recording the entire archiving in the Village and how to provide good service.

\section{Interview}

This method is to get data directly concerned about the data of a matter by way of interviews or question and answer to the parties related to the Empowerment Section, namely $\mathrm{Hj}$. Atikah, S.Pd.

\section{Literature Study}

The method for obtaining information from several sources (literature) such as journals, books, papers, internet, etc. for the needs of analyzing the completion of the research process or as a reference for researchers.

\section{Analysis Method}

PIECES Analysis Method (Performance, Information / Data, Economic, Control / Security, Effectiveness, and Service). The PIECES analysis method is used to determine the current system performance in the administrative services of the Kutabumi Village Office. To illustrate the analysis of a running system that is using UML, which is created using Visual Paradigm Software. 


\section{Design Method}

The system built will be website based, researchers use several software, including:

1. Visualize the system with Visual Paradigm for UML 8.0. Enterprise Edition in making 3 (three) kinds of UML (Unified Modeling Language) diagrams, consisting of Usecase Diagrams, Activity Diagrams, Sequence Diagrams;

2. PHP (Hypertext Processor) as the core Programming Language;

3. Database management using MYSQL (My Structured Query Language);

4. Implement Bootstrap (HTML, CSS, Javascript) as a website interface;

5. XAMPP as a web server

\subsection{Literature Review}

1. Research conducted by Bagus Muhammad Ariyadi and Bahar (2016), entitled "Integrated Service System Application Model in the Kelurahan Office", this study discusses the application of integrated service systems in the kelurahan that help village and community assistance projects in making notification letters. . Then it can be formulated with this application that can improve existing services in making information requests and the public can easily find out what information is in the village office they will be.

2. Research conducted by Dede Abdurahman, Tri Ferga Prasetyo (2018), entitled "Analysis and Design of E-Government in the Transparency of Village Government Systems". This study uses the SDLC method. Then it can be formulated with the design of services in the village based on e-government and can be applied as a supporter in the field of ICT in order to implement excellent village services.

3. Research conducted by Erra Wahyu Puspitarini, Majida Noviyanti, and Asmania Dewi Indria Winata (2017), entitled "Population Data Administration Information System at the Office Koursari Village "this study discusses Design population data administration information system owned the function of making statements more effective and able facilitate the filing system of the Declaration letters issued by the village.

\section{Findings}

In this study, it will be explained about the design of the population administration processing system in the Kutabumi village, Tangerang. In this study, the authors designed a proposal system that could assist operational activities in the service of making administrative letters up to the printing procedures and reports of administrative letters by the public.

\subsection{Problem}

The process of making administrative letters needed by the population up to the printing procedure and the required administrative letter reports will be easier. And the resulting report will be more effective and efficient. In this design, the process of inputting data is carried out with service staff inputting data on the Resident Master form as a source of population information that submits letters as needed. After the data input process is completed and stored, the Service Staff makes a letter according to the needs of the population. After that, it will be continued with the Administrative Staff can do the printing of the letter and the Administrative Staff and Lurah section can view and print reports if needed. At the writing of this scientific journal, the scope of the research includes:

1. Processing a population-based administrative service information system at the Kutabumi Urban Village Office.

2. The process of requesting for a covering letter and other information to realize the urban village that suits your needs.

In the proposed system design that can be explained in use case diagrams, activity 
diagrams, sequence diagrams and class diagrams using Visual Paradigm for UML 6.4 Enterprise Edition.

\subsection{Research Implementation}

\section{SYSTEM DESIGN}

To overcome the current problem, an Information System design for web-based administrative letters is needed so that applicants who want to make a letter can do it at any time. The data needs of the applicant can be directly inputted to the system and letters can be directly printed on the system so that it is more effective and efficient. And the letter needed by the applicant can be directly processed through the system. In this way the applicant can more quickly complete his needs. Also on this system, administrative staff can easily manage applicant data. Applicant registers can be done directly on the system so that there is no stacking of files. This system is certainly integrated in integrated data that can produce a quick, and accurate cover letter report.

\section{Display System Design}

Below is a display of the cover letter system:

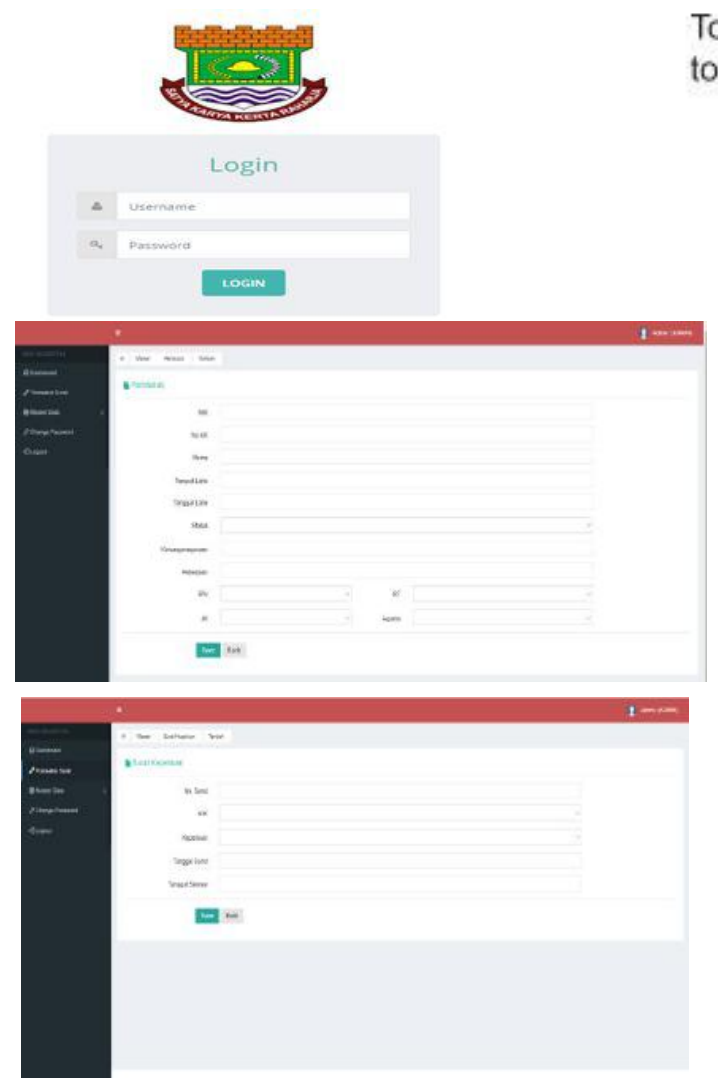

To access this system all users will be directed to the login page

After successfully logging in, it will be directed to the population data input page. Next is the display of population data input.

In this page, there is a letter transaction input that will be made in accordance with what is needed.

\section{Conclusion}

The population administration service information system in the Kutabumi sub-district of Tangerang Regency has the benefit of supporting better service performance. With this system, data processing on administrative letters is more integrated so that people who want to make letters can process data quickly, precisely and accurately. Making a letter into a database thereby reducing errors or human errors. No more stacking of files that can pose a risk of data loss. So the process of making letters is more organized. The report 
produced becomes more effective and efficient.

\section{References}

[1] Abdurahman, Dede, Tri Ferga Prasetyo. (2018). ANALYSIS AND DESIGN OF E GOVERNMENT IN TRANSPARENCY OF THE MAJALENGKA VILLAGE GOVERNMENT SYSTEM: J-Ensitec Journal, Vol. 5 No.

[2] Agustinus, haryanta, et all. (2017). Design of Information Systems Planning and Raw Material Control in Home Industry. Tangerang: Global Sisfotek Journal. Vol.7 No. 1

[3] Alfeno, S, Haris, H., \& Pamungkas, A. B. (2019). Implementation of E-Learning as a Support for Web-Based K-13 Standardization in Improving Learning Competence in Sman 8, Tangerang Regency. Journal of the Medical Information, 5 (2).

[4] Hakim, L. (2017). Designing Alumni Tracer Systems at Musi Rawas Mobile Web-Based Musi STMIK. JUSIM (Journal of Information Systems Musirawas), 2 (2), 108-116.

[5] Soleh, By et al. 2018. Application of Monitoring the Number of Plant Seedlings Using Balance Score Card Analysis in UPTD TPA Rawa Kucing Tangerang City. Jurnal Semnasteknomedia Vol.6 No.1 Hal: 128-132.

[6] Rahardja, U., Aini, Q., \& Thalia, M. B. (2018). Application of Yii-Based Online Payment Confirmation Menu in Higher Education. Creative Information Technology Journal, 4 (3), 174-185.

[7] Warsito, Ary Budi, Muhamad Yusup and Moh lqbal Awi Makaram. (2015). Designing SIS + Using the YII Framework Method at Raharja College. Tangerang: CCIT Journal. Vol.8, No.2 